\title{
KEANEKABAHASAAN DAN PENGEMBANGAN KARAKTER DARI PERSPEKTIF PENDIDIKAN MULTIKULTURAL
}

\author{
Simon Sabon Ola \\ Universitas Nusa Cendana, Kupang \\ sabon_ola@yahoo.com
}

\begin{abstract}
This article discusses the development of character, awareness of diversity and multicultural education. Characters cannot be developed through slogans, rhetoric, or lectures, through various activities that are natural in nature which indicate various attitudes, values and characters. One activity that requires the use of language in a variety of grammar communities. Talks about people with various languages cannot be returned from the question of diversity (multiculturalism). Regarding the rights of each language and taking its speakers, a multicultural perspective is needed to address differences in social interactions and cultural interactions. The agreed interaction process allows the formation of norms and values that lead to the formation of character.Based on observing the situation of diversity with various characteristics, it can characterize that can be developed and developed from the situation of diversity. These characters were identified through various language typologies, various repertoires, awareness about motherhood, dynamic diglossia, characteristics of language choice, the role of Indonesian in multiculturalism perspective. Approved characters, among others: agreed, mutually agreed, social care, religious, national spirit and love of the motherland. Thus, diversity can be a medium of education and character development in the development of multiculturalism.
\end{abstract}

Keywords: multilingual, character development, multiculturalism.

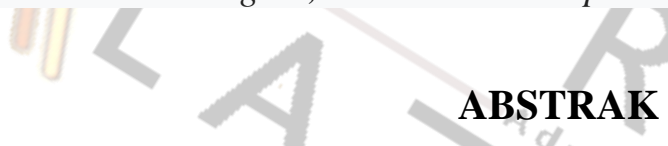

Artikel ini membahas tentang pengembangan karakter, kesadaran akan keberagaman dan pendidikan multikultural. Karakter tidak dapat dikembangkan melalui slogan, retorika, atau ceramah, melalui berbagai kegiatan yang bersifat alamiah yang menunjukkan berbagai sikap, nilai, dan karakter. Salah satu kegiatan yang menuntut penggunaan bahasa dalam berbagai komunitas tata bahasa. Berbicara tentang masyarakat dengan berbagai bahasa tidak bisa dilepaskan dari pertanyaan tentang keberagaman (multikulturalisme). Mengenai hak setiap bahasa dan penuturnya, diperlukan perspektif multikultural untuk mengatasi perbedaan interaksi sosial dan interaksi budaya. Proses interaksi yang disepakati memungkinkan terbentuknya norma-norma dan nilai-nilai yang mengarah pada pembentukan karakter. Berdasarkan pengamatan terhadap situasi keberagaman dengan berbagai karakteristik, maka dapat dibentuk karakter yang dapat dikembangkan dari situasi keberagaman. Karakter-karakter tersebut diidentifikasi melalui berbagai tipologi bahasa, berbagai repertoar, kesadaran tentang keibuan, diglosia yang dinamis, ciri-ciri pilihan bahasa, peran bahasa Indonesia dalam perspektif multikulturalisme. Karakter yang disetujui antara lain: setuju, disepakati bersama, peduli sosial, religius, semangat kebangsaan dan cinta tanah air. Dengan demikian keberagaman dapat menjadi media pendidikan dan pengembangan karakter dalam pembangunan multikulturalisme.

Kata kunci: multibahasa, pengembangan karakter, multikulturalisme.

\section{PENDAHULUAN}

Pengembangan karakter kini tengah menjadi perhatian seluruh bangsa Indonesia. Hal ini disebabkan oleh karena realita menunjukkan bahwa soal karakter manusia Indonesia, terutama generasi muda sedang menjadi keprihatinan bangsa. Gaya hidup generasi muda yang hedonis dan pola hidup instan telah turut berkontribusi bagi terjadinya degradasi nilai. Ini merupakan persoalan krusial bangsa, bahkan dapat 
dikategorikan sebagai bencana kemanusiaan, yang meskipun telah menyedot perhatian, namun belum menjadi kesadaran kolektif.

Karakter tidak dapat dibangun dengan hanya wacana, retorika, dan ungkapan-ungkapan verbalistik, akan tetapi harus dikondisikan melalui berbagai cara dan pendekatan. Pengembangan karakter harus "digempur" dari berbagai kondisi agar tertanam secara komprehensif pada setiap individu yang kemudian secara bersama-sama membentuk komunitas yang berkarakter kuat.

Salah satu kondisi yang dapat dieksploitasi untuk pengembangan karakter ialah situasi keanekabahasaan dan keanekabudayaan. Keanekabahasaan dan keanekabudayaan patut diposisikan sebagai sarana pembangun karakter. Bahasa dan kebudayaan yang keberadaannya pada setiap guyup tutur dan guyup budaya senantiasa sarat nilai dapat dijabarkan ke dalam butir-butir karakter.

Salah satu pilar bagi bangunan NKRI ialah kesatuan dalam kebhinekaan. Kebhinekaan/ keberbedaan yang terlahir secara alamiah perlu dipelihara dan dilestarikan dengan prinsip saling melengkapi agar tercipta interaksi yang humanis dan penuh kedamaian, serta memupuk rasa persatuan di antara sesama anak bangsa. Hal ini merupakan bagian gari kekuatan moral yang mampu memperkokoh integrasi dan meredam konflik yang menjurus disintegrasi bangsa.

Studi bahasa dan budaya yang berlandaskan pandangan strukturalis yang hanya sampai pada membedah bentuk, fungsi, dan makna perlu diperluas perspektifnya. Peran aksiologis dari bidang ilmu kebahasaan dan ilmu budaya, termasuk perpaduan antara keduanya harus diungkapkan secara lebih mendalam. Dari pencermatan aksiologis itulah dapat secara cermat pula diungkapkan karakter pemilik keanekabahasaan dan keanekabudayaan.

Tahun 2045 Bangsa Indonesia mencanangkan pencapaian Indonesia Emas, dan ketika itu Indonesia diharapkan masuk dalam urutan 10 besar Negara di dunia dengan pendapat per kapita terbesar. Ini merupakan peluang, sekaligus tantangan yang membutuhkan sumber daya manusia yang berkualitas dan berdaya saing global. Krisis serius menyangkut sumber daya manusia di Indonesia ialah dekarakterisasi yang besar kontribusinya bagi munculnya kendala di berbagai sektor pembangunan. Jika demikian, pendidikan dan pengembangan karakter mutlak diperlukan untuk menciptakan agen pembangunan yang bermutu dan berdaya saing.

Melalui makalah ini penulis mencoba mengidentifikasi dan memerikan butir-butir karakter yang tersirat di balik siatuasi keanekabahasaan di Indonesia. Identifikasi dan perian/ deskripsi ini dilakukan dalam perspektif pendidikan multikultural. Makalah ini juga dimaksudkan untuk menggugah, sekaligus "menggugat" sejumlah fenomena untuk didiskusikan untuk selajutnya didalami melalui penelitian atau pun kajian ilmiah.

\section{KONSEP}

\subsection{Keanekabahasaan}

Secara etnomolgis, kata keanekabahasaan terdiri dari kata aneka dan bahasa yang diberi konfiks ke-an. Kata keanekabahasaan, berdasarkan etimologis sebagaimana dimaksud di atas mengandung arti 'hal beranekabahasa', yang sesungguhnya merupakan terjemahan kata multilingualism dalam bahasa Inggris. Konsep ini merujuk pada pemakaian beberapa bahasa oleh seseorang atau sekolompok orang. 
Konsep keanekabahasaan kurang familiar dalam pustaka sosiolinguistik. Sosiolinguis lebih lazim menggunakan konsep kedwibahasaan, yang di dalamnya tercakup pula keanekabahasaan sebagai fenomena sosial meskipun Mackey (dalam Fishman, 1970:554) berpendapat: "bilingualism is the property of individuals". Adler (1977) sebagaimana dikutip Romaine (1995:23), bahwa tidak mungkin membedakan kedwibahasaan (dan keanekabahasaan) sebagai fonomena individual dengan kedwibahasaan sebagai fenomena sosial.

Ketercakupan konsep keanekabahasaan di dalam konsep kedwibahasaan dapat dilihat di dalam berbagai pendapat (Ola, 2013:49), antara lain:

a. Einar Haugen (1966), kedwibahasaan adalah kemampuan seseorang menghasilkan tuturan yang lengkap dan bermakna dalam bahasa lain; 'bahasa lain' dapat saja lebi dari satu bahasa.

b. J.Wolff (1974), kedwibahasaan adalah penggunaan dua bahasa atau lebih oleh seseorang atau sekelompok orang (penggunaan lebih dari dua bahasa sama artinya dengan keanekabahasaan).

Dengan beranalogi terhadap pendapat Hamers dan Blanc (dalam Romaine, 1995:23) yang menggunakan istilah bilingualism dan bilinguality, dapat pula dibedakan antara multilingualism dan multilinguality. Yang pertama mengacu pada kemampuan, sedangkan yang kedua mengacu pada kebiasaan; atau dapat dikatakan bahwa multilingualism sebagai kompetensi, sedangkan multilinguality sebagai performansi. Dengan demikian, keanekabahasaan adalah kebiasaan seseorang atau sekelompok orang untuk menggunakan dua bahasa atau lebih sesuai dengan repertoar yang dimilikinya. Penggunaan bahasa(-bahasa) di dalam masyarakat beranekabahasa (multilingualism) mengandung nilai sosial yang dapat diksplorasi untuk menemukan fungsinya sebagai wadah pembentukan karakter.

\subsection{Karakter}

Kata karakter diadopsi dengan mengadaptasi bentuk character (Ing.), yang berarti 'sikap', 'watak' . Watak mencakup dikotomi baik dan buruk sebagai ukuran relatif. Ukuran relatif itu pun masih bersifat kontekstual, meskipun ada pula ukuran baik atau buruk yang bersifat universal. Ukuran baik-buruk itulah yang menjadi acuan nilai bagi individu di dalam memosisikan dirinya di dalam suatu komunitas menurut kualifikasi karakter.

Karater dapat dipilah menjadi: (1) karakter kuat dan lemah; dan (2) karakter baik dan buruk. Karakter kuat, misalnya: tangguh, ulet, mempunyai daya juang yang tinggi, atau pantang menyerah. Karakter lemah; misalnya penakut, tidak berani mengambil resiko, pemalas, cepat menyerah, belum apa-apa sudah menyerah, dan sebagainya. Karakter baik; seperti jujur, terpercaya, rendah hati, dan sebagainya. Karakter jelek, misalnya licik, egois, serakah, sombong, dan sebagainya.

Berbagai karakter tersebut tampak di dalam perilaku berbahasa pada masyarakat beranekabahasa (multilingual). Karakter baik dan kuat perlu dikembangkan, sebaliknya karakter buruk dan lemah sedapat mungkin direduksi melalui kesadaran beranekabahasa dan beranekabudaya. Kesadaran itulah yang turut membangun sikap berbahasa sebagai pencerminan dari sikap budaya. Dengan kata lain, karakter hanya bisa dikembangkan secara baik melalui berbagai aktivitas interaksi; tanpa interaksi tidak ada nilai dan norma, dan jika demikian, tidak pernah akan ada karakter dan pengembangan atau penguatannya. 


\subsection{Pendidikan Multikultural}

Pendidikan multikultural adalah konsep baru dalam dunia pendidikan. Pendidikan multikultural sebenarnya merupakan sebuah gerakan pembaharuan dalam bidang pendidikan. Gerakan pembaharuan dimaksud bertujuan memberikan kesempatan yang sama bagi siswa untuk berprestasi. Banks (dalam Sutarno, 2007:1-21) berpendapat: "Pendidikan multikultural adalah ide, gerakan pembaharuan pendidikan, dan proses pendidikan yang tujuan utamanya adalah untuk mengubah struktur lembaga pendidikan supaya siswa, baik pria maupun wanita, siswa berkebutuhan khusus, dan siswa merupakan anggota dari kelompok ras, etnis dan kultur yang bermacam-macam itu akan memiliki kesempatan yang sama untuk mencapai prestasi akademik di sekolah.”

Di luar hal pendidikan formal, pendidikan multikultural berperan di dalam membangun kesadaran keanekabudayaan. Sehubungan dengan bahasa sebagai salah satu unsur kebudayaan, dapatlah diklaim bahwa keanekabudayaan itu dapat pula memupuk kesadaran keanekabahasaan, yang karakteristik interaksi antara anggota guyup tuturnya turut mencirikan karakter, sekaligus membentuk karakter. Pendidikan multikultural memberikan ruang bagi perbedaan, menghargai perbedaan, dan menolak pembedaan/ diskriminasi. Di dalam situasi ini, hak hidup setiap bahasa dijamin oleh penuturnya sebagai pemangku kepentingan, dan dilindungi oleh pemerintah sebagai pemangku kebijakan.

\section{KEANEKABAHASAAN DAN PEMBENTUKAN KARAKTER}

\subsection{Keanekaragaman Tipologi, Penciri Karakter Penutur}

Hakikat bahasa sebagaimana dikedepankan para linguis sejagad membenarkan asumsi bahwa terdapat sifat kesejagadan bahasa (language universals) (Greenberg dalam Malmkjaer \& Anderson, eds. 1991:279_284; Comrie, 1983:2004-209) . Namun demikian, berbagai kajian linguistik secara mikro pun menemukan fakta bahwa terdapat kekhasan/ keunikan bahasa yang tampak pada kaidah fonologi, morfologi, dan sintaksis. Kekhasan dimaksud dalam terminologi linguistik dikenal sebagai tipologi bahasa (language typology).

Kajian linguistik mikro sudah tentu hanya sampai pada taraf menemukan kaidahkaidah, dan jika ada pengecualian (idiosinkresi), maka segera muncul klaim bahwa pengecualian itu dapat diterangkan secara pragmatik, baik secara sosiologis, psikologis, maupun secara kultural. Kondisi ini memunculkan lahirnya linguistik makro atau pun linguistik lintas bidang.

Di samping pengecualian yang memerlukan penjelasan yang bersifat lintas bidang, kaidah-kaidah yang dimiliki suatu bahasa dapat pula diekspolitasi untuk menjelaskan karakter penuturnya. Karakter dimaksud terbentuk karena cara pandang/ pandangan dunia (world view) berdasarkan bentuk lingual yang dimiliki dan digunakan. Pandangan ini dapat dielaborasi ke dalam pertanyaan-pertanyaan mengenai kemungkinan penelusuran karakter penutur suatu bahasa yang dibentuk oleh tipologi bahasanya, seperti berikut ini.

a. Apakah terdapat perbedaan karakter antara penutur bahasa yang bertipologi bahasa tonal dengan bahasa nontonal?

b. Apakah terdapat perbedaan karakter antara penutur bahasa yang bertiplogi aglutinatif dengan bahasa isolasi? 
c. Apakah terdapat perbedaan karakter antara penutur bahasa yang bertiplogi urutan kata (word order) SVO dengan bahasa yang bertipologi urutan kata SOV, atau pun VOS?

Ketiga pertanyaan di atas diajukan untuk menggelitik para pakar dan peneliti bahasa bahwa terdapat tipologi fonologi, morfologi, dan sintaksis yang dapat dimanfaatkan, baik secara antropolinguistik maupun semiotik dalam mengklaim hubungan antara tipologi dimaksud dengan karakter penuturnya. Hal ini memerlukan cara kerja induktif dan deduktif secara silmultan agar tidak mengklaimnya secara prematur. Kita boleh berpendapat bahwa agaknya prematur jika kita mengatakan bahwa orang-orang yang memiliki bahasa yang bertipologi SVO cenderung lebih mementingkan subjek. Apalagi secara apariori memvonis guyup tuturnya sebagai komunitas yang cenderung bersifat subjektif. Atau sebaliknya, orang-orang yang memiliki bahasa yang bertipologi VSO cenderung mengutamakan kerja, lalu diklaim pula bahwa mereka memiliki karakter sebagai pekerja keras, rajin, dan ulet. Mungkin lebih tepat jika klaim ini dijadikan asumsi untuk kemudian dibuktikan melalui pendekatan keilmuan yang mengeksplanasi keterkaitan antara tipologi bahasa dengan karakter guyup tuturnya.

Tugas linguistik, di samping membedah keteraturan dan ketidakteraturan (ideosinkresi) secara mikro, juga membuktikan bahwa sistem mikro tersebut berkaitan dengan perilaku masyarakat tutur. Dengan demikian, maka tidak hanya tipologi urutan kata sebagaimana diuraikan di atas yang dapat menjadi pintu masuk untuk mencermati karakter (budaya) individu dan karakter komunitas, tetapi juga tipologi lain pada tataran sintaksis, seperti frasa, di samping tipologi fonologi dan morfologi seperti yang dirumuskan pada pertanyaan a dan $b$ terdahulu.

\subsection{Pembentukan Karakter karena Keanekaragaman Repertoar}

Setiap orang memiliki khasanah verbal atau kekayaan bahasa yang digunakan berdasarkan kaidah-kaidah sosiolinguistik. Repertoar kebahasaan dapat berupa jumlah kosa kata dan tingkat kesadaran norma suatu bahasa yang dimiliki oleh seseorang, dapat pula berupa jumlah bahasa yang dikuasai oleh seseorang. Dari sisi kompetensi, repertoar merupakan milik individu, namun penggunaan repertoar oleh individu untuk berkomunikasi dalam konteks sosial menunjukkan bahwa repertoar pun menjadi milik masyarakat.

Orang-orang yang berbeda bahasa memiliki cara berinteraksi yang berbeda pula (Wierzbicka, 1991:2 - 4). Dalam masyarakat yang beranekabahasa sangat diperlukan daya akomodasi agar perbedaan yang berpotensi konflik sedapat mungkin direduksi agar interaksi berlangsung secara harmonis di satu sisi, dan di sisi yang lain masingmasing memperoleh hak hidup sebagaimana unsur-unsur budaya lainnya.

Keanekabahasaan berimplikasi pada beberapa fenomena lain, antara lain: pilihan bahasa, sikap bahasa, persaingan bahasa, pergeseran dan ketahanan bahasa, diglosia dan poliglosia. Adanya fenomena-fenomena tersebut dapat membentuk karakter masyarakat yang beranekabahasa, sebagaimana uraian berikut ini.

\subsubsection{Kesadaran Berbahasa Ibu}

Keanekabahasaan yang terdiri dari individu dan masyarakat beranekabahasa merupakan sebuah kondisi yang terbentuk dari proses perluasan repertoar dari bahasa pertama (B1) atau bahasa ibu (mother tongue) ke B2, dan seterusnya. B1 dikuasai oleh seseorang melalui proses pemerolehan, sedangkan B2, dan seterusnya dikuasai melalui pembelajaran. Penguasaan melalui pemerolehan dimulai dengan pemakaian 
secara alamiah dan diikuti penguasaan kaidah secara intuitif, sebaliknya penguasaan melalui pembelajaran cenderung dimulai dari pengenalan kaidah dan diikuti dengan pemakaian.

Keberadaan bahasa ibu dan bahasa-bahasa lainnya dalam suatu masyarakat beranekabahasa secara intuitif melahirkan sikap positif terhadap bahasa ibu. Sikap positif itu antara lain mempertahankan dan memberikan daya hidup bagi bahasa ibu, dan pada saat yang sama bahasa lain pun memperoleh kesempatan untuk hidup, artinya pula memberikan kesempatan kepada orang lain untuk juga mempertahankan bahasa ibunya. Memberikan kesempatan masing-masing penuutur bahasa ibu untuk mempertahankan bahasanya dapat memupuk karakter demokratis dan saling menghargai.

Karakter ini tumbuh secara sangat alamiah sebagaimana kealamiahan pemakaian bahasa. Karakter dibangun dan dikembangkan pada setiap anak bangsa tanpa perlu banyak beretorika melalui ceramah dan tutorial tanpa tindakan nyata. Karakter semestinya dibangun melalui keberlangsungan berbagai aktivitas yang bersifat interaksional. Pemakaian bahasa dalam masyarakat beranekabahasa merupakan aktivitas interaksional yang menunjukkan bagaimana penutur menyikapi mitra tutur, bahasa pertama mitra tutur, cara berinteraksi yang diperlihatkan oleh mitra tutur, yang kesemuanya merupakan wadah penguatan karakter.

Setiap bahasa memiliki kekhasan sistem semantik. Kekhasan ini tidak jarang menimbulkan konflik semantik sebagai konsekuensi dari perbedaan semantik lintas bahasa. Bentuk lingual yang sama pada sejumlah bahasa sering memiliki rujukan berupa benda ataupun konsep yang berbeda antarbahasa. Perbedaan itu dapat menumbuhkan saling pengertian, di samping penting untuk menyadarkan setiap pemakai bahasa untuk bersikap kreatif dan adaptif dalam menggunakan bahasa, termasuk juga ciri kontekstual penggunaannya.

\subsubsection{Kedinamisan Diglosia}

Keanekabahasaan pada umumnya cenderung berdiglosik. Diglosia merupakan situasi keanekabahasaan yang menunjukkan adanya perbedaan gengsi antarbahasa; bahasa tertentu dipandang mempunyai kedudukan tinggi $(\mathrm{T})$, sementara bahasa lainnya dipandang berkedudukan rendah (R). Diglosia merupakan sebuah kondisi yang menyadarkan setiap penutur bahasa untuk menerima gengsi bahasanya.

Diglosia bersifat relatif, tinggi-rendahnya prestise suatu bahasa tidak bersifat statis. Diglosia bersifat dinamis sesuai dengan fungsi dan peran sosial setiap bahasa pada ranah-ranah pemakaian di dalam suatu masyarakat tutur. Diglosia yang bersifat relatif ini pada hakikatnya mencerminkan tidak adanya hegemoni bahasa, dengan demikian tidak ada pula hegemoni antarpemakai bahasa dalam masyarakat yang beranekabahasa.

Kesadaran terhadap kedinamisan diglosia dapat membentuk karakter peduli sosial. Ciri karakter peduli sosial ialah menerima perbedaan yang tidak diskriminatif. Perbedaan tidak dijadikan intrumen untuk mengagungkan satu kelompok pemakai bahasa dan menistakan/ merendahkan kelompok pemakai bahasa lainnya. Kita dapat belajar dari relativitas diglosia untuk menguatkan kesadaran mengenai relativitas hierarki sosial individu ataupun kelompok. Dengan demikian, kelompok dominan tidak merasa berkuasa dan superior, sebaliknya kelompok minoritas tidak berada di bawah kekuasaan dan tidak pula terbelenggu oleh ketidakberdayaan.

Karakter peduli sosial juga tampak pada komunitas yang memelihara keanekabahasaan. Bertahan dalam situasi keanekabahasaan sudah tentu dapat memupuk 
sikap tenggang rasa. Mempertahankan keanekabahasaan berimplikasi pada memberikan ruang dan hak bagi suatu bahasa untuk hidup dan berkembang secara alamiah, sekaligus menempatkan penuturnya sebagai bagian dari totalitas kosmos.

Kerelatifan diglosia dapat menyadarkan penutur bahasa(-bahasa) tentang relativitas peran sosial dari setiap individu dalam suatu komunitas. Setiap peran, penting atau puntidak penting, tidak bersifat permanen. Seseorang mempunyai peran penting dalam domain tertentu, namun tidak demikian halnya ketika ia masuk pada domain lainnya. Realitas demikian dapat meredam sikap sombong dan egois.

\subsubsection{Karakteristik Pilihan Bahasa}

Masyarakat beranekabahasa sulit menghindari pilihan bahasa, yang mencakup: campur kode, alih kode, silang kode, Pilihan berupa campur kode (code mixing) dan alih kode (code shifting) merupakan strategi untuk memperoleh keharmonisan komunikasi. Keharmonisan interaksi yang dibangun melalui pilihan bahasa dapat membangun karakter kreatif, terutama kreativitas berbahasa.

Kreativitas berbahasa sebagai sebagai ciri pembeda antara manusia dengan binatang merupakan pencetus, sekaligus pemupuk kreativitas-kreativitas lainnya. Kreativitas itu pulalah yang mencirikan perbedaan antara individu yang pintar dengan individu yang cerdas. Orang yang pintar belum tentu cerdas; (ke)cerdas(an) dicirikan oleh kreativitas yang tercermin pula di dalam kreativitas berbahasa.

Pilihan campur kode dan alih kode dalam siatusi diglosia dengan arah campur kode atau alih kode ke atas (ke bahasa yang tergolong tinggi) dapat menggambarkan keangkuhan pemakainya. Pilihan berupa campur kode dan alih kode tidak perlu terjadi seandainya pemakainya sudah meniati menggunakan pilihan itu untuk keperluan meningkatkan gengsi. Sebaliknya pilihan itu terpaksa dilakukan jika terdapat kendala semantik. Kendala dimaksud berupa ketidaktersediaan leksikon tertentu dalam bahasa yang sedang digunakan. Dengan demikian, pemakai bahasa terpaksa memilih leksikon bahasa lain untuk menyampaikan maksudnya. Demikian pula halnya dengan pengertian yang spesifik yang hanya dapat diterangkan dalam bahasa tertentu mendorong seseorang untuk bealih dari kode (bahasa) yang sedang digunakan ke kod lainnya.

Pilihan lainnya berupa silang kode (code crossing) tidak didasarkan pada alasan keharmonisan komunikasi. melainkan pada alasan untuk menjadikan dari sebagai bagian dari suatu kelompok/ komunitas. Hasrat untuk menjadi "orang dalam" atau in group/ insider secara ekstrim semacam ini merupakan pilihan bahasa yang jarang ditemukan, kecuali jika salah satu pelibat interaksi berada dalam situasi belajar bahasa kedua. Meskipun demikian, pilihan bahasa ini dapat menjadi model pengembangan sikap integratif dan meredam perilaku disintegratif dalam semua tingkat komunitas, termasuk komunitas bangsa.

\subsubsection{Keanekabahasaan sebagai Anugerah Tuhan}

Subjudul ini mungkin dianggap berlebihan dalam konteks pembicaraan keanekabahasaan. Namun dalam konteks pembangunan dan pendidikan karakter di Indonesia, hal ini menjadi sangat penting, terutama yang berkaitan dengan komptensi inti dalam KK 2013 untuk pendidikan dasar dan menengah. Rumusan Kompetensi inti 1 (KI.1, kompetensi sikap spiritual) dalam KK 2013 menunjukkan bahwa seluruh materi pembelajaran dilandasi oleh kesadaran akan anugerah Tuhan Yang Mahakuasa.

Dalam kaitan dengan keanekabahasaan, kesadaran akan anugerah Tuhan itu takterbantahkan. Artinya, keanekabahasaan dapat membangun karakter religius. 
Sehubungan dengan itu, keanekabahasaan mesti menjadi topik dalam pembelajaran, baik pada pendidikan formal, informal, maupun nonformal. Dengan menjadikan keanekabahasaan sebagai topik pembelajaran, para peserta didik disadarkan akan keanekaragaman, di samping sebagai anugerah Tuhan, juga sebagai kekayaan, kekuatan, kesempurnaan, dan keindahan. Keanekabahasaan sebagai kekayaan karena berjumlah banyak, sebagai kekuatan karena sebagai wadah ekspresi berbagai budaya, sebagai kesempurnaan karena saling melengkapi fungsi dan peran, dan sebagai keindahan karena tampilan yang berbeda, bahkan khas.

\subsection{Peran Bahasa Indonesia}

Bahasa Indonesia (BI) mempunyai fungsi dan kedudukan yang sangat penting di dalam kehidupan berbangsa dan bernegara. BI merupakan pilihan utama untuk mengatasi kesulitan berkomunikasi antara pelibat yang berbeda bahasa daerah, karena itu BI dikategorikan sebagai lingua franca. Fungsi lingua franca kemudian berkembang menjadi fungsi-fungsi strategis berkaitan dengan kehidupan berbangsa dan bernegara, dan mendapatkan kedudukan sebagai bahasa Negara dan bahasa nasional.

Dalam kedudukannya sebagai bahasa nasional, bahasa Indonesia berfungsi sebagai:

(a) lambang kebanggaan nasional;

(b) alat pemersatu berbagai suku yang berbeda bahasa daerahnya;

(c) lambang identitas nasional;

(d) alat perhubungan antardaerah.

Sementara sebagai bahasa negara, bahasa Indonesia berfungsi sebagai:

(a) bahasa resmi kenegaraan;

(b) bahasa pengantar resmi pada lembaga pendidikan;

(c) bahasa pembangunan;

(d) bahasa dalam pengembangan budaya dan iptek.

Fungsi-fungsi tersebut di atas menyadarkan setiap warga Negara Indonesia untuk menempatkan bahasa Indonesia sebagai jatidiri bangsa Indonesia. Kesadaran ini kemudian membentuk karakter semangat kebangsaan dan cinta tanah air.

Sebagai jatidiri bangsa, di samping bendera, lambang Negara, dan lagu kebangsaan (UU. No. 24 Tahun 2009), bahasa Indonesia memberikan corak keindonesiaan pada setiap warga negaranya. Hal ini tidak berarti bahwa bahasa Indonesia adalah satusatunya bahasa yang diakui keberadaannya menurut Undang-Undang Dasar 1945, sebagaimana maksud dari Sumpah Pemuda 1928, "Kami putera dan puteri Indonesia menjunjung tinggi bahasa persatuan, bahasa Indonesia." Rumusan Sumpah Pemuda itu mengandung maksud bahwa di samping bahasa Indonesia sebagai bahasa persatuan, masih ada bahasa lainnya yang memiliki fungsi kelokalan.

Bahasa yang memiliki fungsi kelokalan dimaksud, antara lain bahasa daerah. Bahasa-bahasa daerah di Indonesia dijamin keberadaannya oleh negara. Bahasa daerah di Indonesia yang demikian banyak ,yang berarti pula banyaknya budaya daerah, sudah tentu mendukung eksistensi bahasa Indonesia sebagai bahasa persatuan. Atas dasar persatuan itulah kemudian lahirlah semangat kebangsaan (nasionalisme) dan cinta tanah air. Semangat tersebut yang ditopang oleh lambang kebanggaan dan identitas bangsa, termasuk bahasa Indonesia, diharapkan dapat meredam konflik sosial yang mungkin saja menjurus ke disintegrasi bangsa sebagai pengingkaran/ negasi terhadap semangat persatuan dan kesatuan bangsa. 


\section{KESADARAN MULTIKULTURALISME}

Kesadaran terhadap kebudayaan sendiri dan menghubungkannya dengan kebudayaan orang/ kelompok lain melahirkan dikotomi in group vs. out group. Dikotomi ini memungkinkan lahirnya kesadaran multikulturalisme. Kesadaran ini penting untuk meredam berbagai penyakit budaya, antara lain: stereotip, prasangka, dan diskriminasi (bdk. Sihabudin, 2011:117-128).

Kesadaran multikulturalisme, sama halnya dengan kesadaran keanekabahasaan, melahirkan konsep identitas. Konsep ini sangat penting di dalam komunikasi lintas bahasa dan lintas budaya. Dalam hal berbahasa pada masyarakat beranekabahasa, identitas "saya/ kami" haruslah dimaknai dan dipahami dalam konteks keberadaan "mereka" sehingga lahirlah konsep yang menjembatani keduanya, yakni "kita". Jika yang baik, bagus, unggul, dan bermartabat hanyalah "kita", maka secara tidak langsung terlahirlah "mereka", yang sudah tentu beroposisi semantik berupa jelek, buruk, dan tidak bermartabat. Perilaku semacam ini tampak pada pemberian cap atau label negatif kepada orang atau kelompok lain. Hal ini disebut sebagai stereotip.

Dalam konteks keanekabahasaan, stereotip tidak perlu terjadi jika setiap penutur dan pemakai bahasa menghayati secara sungguh-sungguh fungsi dari masing-masing bahasa. Bahasa besar, bahasa kecil, bahkan bahasa-bahasa yang terancam punah pun memiliki fungsi ekspresif bagi penuturnya. Sehubungan dengan itu, setereotip mungkin saja diarahkan pada suatu komunitas pemilik budaya, namun tidak pada bahasa sebagai unsur budaya yang mereka miliki.

Stereotip terjadi karena kegagalan proses akulturasi. Kegagalan proses akulturasi juga memunculkan gejala prasangka dan diskriminasi. Dalam kehidupan sosial sering terjadi proses generalisasi yang didasarkan pada fakta dan data yang terbatas terhadap eksistensi dan perilaku suatu komunitas. Generalisasi yang mengarah ke penempatan kelompok sendiri beroposisi dengan kelompok lain sehingga memberikan kesan membeda-bedakan secara negatif (diskriminasi).

Berbagai penyakit budaya sebagaimana tersebut di atas disebabkan oleh keterbatasan kompetensi sosial dan kompetensi budaya. Kompetensi ini mencakup kemampuan berinteraksi sosial dan interaksi kultural. Kemampuan berinteraksi merupakan wujud kemampuan beradaptasi budaya sebagai bagian dari kesadaran multikultural, termasuk kesadaran akan keanekaragaman dan perbedaan bahasa. Hal ini berkaitan erat dengan prinsip pendidikan yang digagaskan UNESCO, yang salah satu di antaranya ialah belajar untuk hidup bersama (learning lo live together). Prinsip ini menekankan pada kemampuan beradaptasi terhadap berbagai perbedaan, baik antarindividu maupun antarkelompok.

\section{PENUTUP}

Keanekabahasaan, pengembangan karakter, dan pendidikan multikultural adalah tiga unsur dari sebuah sistem di dalam pengembangan karakter. Kesadaran multikulturalisme memberikan ruang bagi berkembangnya keanekabahasaan, dan situasi keanekabahasaan secara alamiah dapat membentuk karakter penuturnya. Kesadaran multikulturalisme dan keanekabahasaan membangun sikap solider dan antihegemoni; sikap yang harus dikembangkan dalam konteks pengembangan karakter keindonesiaan.

Keanekabahasaan dan multikulturalisme penopang spirit kebhinekatunggalikaan yang merupakan identitas Bangsa Indonesia. Oleh karena itu, sejatinya 
keanekabahasaan dan multikulturalisme itu harus terus dikembangkan untuk memperkuat identitas keindonesiaan. Dari sinilah seluruh warga bangsa belajar menjadi diri sendiri, baik secara kultural maupun secara sosial politik dalam konteks pergaulan internasional. Situasi ini menjadi momentum bagi Indonesia untuk memperkuat jadidirinya sebagai bangsa yang menghargai perbedaan. Dengan menghargai perbedaan Indonesia terbebas dari konflik, leluasa mencapai daya saing, dan banyak persoalan bangsa yang dapat diselesaikan. 


\section{DAFTAR PUSTAKA}

Comrie, Bernard. 1983. Language Universals and Linguisitic Typology, Syntax and Morphology. Oxford: Basil Blackwell Publishers.

Direktorat Jenderal Pendidikan Tinggi Depdiknas. 2009. Sertifikasi Guru dalam Jabatan, Buku 5: Rambu-Rambu Pelaksanaan Pendidikan dan Latihan Profesi Guru. Jakarta.

Grosjean, F. 1982. Life with Two Languages, An Introduction to Bilingualism. Cambridge: Harvard University Press.

Hamalik, Oemar. 2003. Pendidikan Guru berdasarkan Pendekatan Kompetensi. Jakarta: Bumi Aksara.

Holmes, Janet. 1994. An Introduction to Sociolinguistics. London and New York: Longman.

Kementrian Pendidikan Nasional. 2010. Buku Induk Pembangunan Karakter. Jakarta.

Koentjaraningrat. 1981. Kebudayaan, Mentalitas dan Pembangunan. Jakarta: PT Gramedia.

Malmkjaer, Kirsten \& James Anderson (eds). 1991. The Linguistics Encyclopedia. London \& New York: Routledge.

Ola, Simon Sabon. 2013. Buku Ajar Sosiolinguistik. Kupang: Penerbit Lembaga Penelitian Undana.

Romaine, Suzanne. 1995. Bilingualism. Cambridge: Blackwell.

Sumarsono. 1993. Pemertahanan Bahasa Melayu Loloan di Bali. Jakarta: Pusat Pembinaan dan Pengembangan Bahasa.

Samovar, Larry A., Richard E. Porter dan Edwin R. McDaniel. 2010. Komunikasi Lintas Budaya (Terjemahan Indri Margaretha Sidabalok). Jakarta: Salemba Humanika.

Sihabudin, Ahmad. 2011. Komunikasi Antarbudaya, Satu Perspektif Multidimensi. Jakarta: PT Bumi Aksara.

Saville- Troike, Muriel. 1982. The Ethnography of Communication. Oxford: Basil Blackwell Publisher.

Tim Penyusun. 2012. Buku Panduan Pendidikan Karakter Universitas Nusa Cendana. Kupang.

Undang-Undang Republik Indonesia Nomor 24 Tahun 2009 tentang Bendera, Bahasa, dan Lambang Negara, serta Lagu Kebangsaan Indonesia Raya.

Wierzbicka, Anna. 1992. Semantics, Culture, and Cognition. Oxford: Oxford University Press. 